\title{
Anticarcinogenesis effect of Gynura procumbens (Lour) Merr on tongue carcinogenesis in $4 \mathrm{NQO}-$ induced rat
}

\author{
D. Agustina*, Wasito**, S.M. Haryana***, and A. Supartinah **** \\ * Oral Medicine Department, Faculty of Dentistry, Gadjah Mada University \\ ** Pathology Department, Faculty of Veterinary Medicine, Gadjah Mada University \\ *** Histology and Molecular Biology Department, Faculty of Medicine, Gadjah Mada University \\ ***** Pedodontics Department, Faculty of Dentistry, Gadjah Mada University \\ Jogjakarta - Indonesia
}

\begin{abstract}
In Indonesia Gynura procumbens (Lour) Merr leaves have been long used as various cancers medication. Many in vitro and in vivo studies have demonstrated anticarcinogenesis of ethanol extract of Gynura procumbens leaves. The aim of this study was to investigate the anticarcinogenesis of the ethanol extract of Gynura procumbens leaves on 4 nitroquinoline 1-oxide (4NQO)-induced rat tongue carcinogenesis. Fifty six 4 week old male Sprague Dawley rats were used in this study and divided into 7 groups. Group 1, 2 and 3 were lingually induced by $4 N Q O$ for 8 weeks. In groups 2 and 3 the extract was given simultaneously with or after $4 N Q O$ induction finished, each for 10 weeks and 26 weeks, respectively. Groups 4, 5 and 6 were induced by $4 N Q O$ for 16 weeks. However, in groups 5 and 6 the extract was given as well simultaneously with or after the $4 N Q O$ induction, each for 18 weeks, respectively. Group 7 served as the as untreated control group. The results from microscopical assessment showed that tongue squamous cell carcinomas (SCC) developed in 100\% (3/3) of group 1. However, only 33.3\% (2/6) and 25\% (2/8) of rats in groups 2 and 3 , respectively demonstrated tongue SCC. Among groups 4, 5 and 6, no significant difference of tongue SCC incidence was observed. From these results it is apparent that the ethanol extract of Gynura procumbens leaves could inhibit the progression of $4 N Q O$ induced rat tongue carcinogenesis in the initiation phase.
\end{abstract}

Key words: Gynura procumbens, $4 N Q O$, rat, tongue carcinogenesis

Correspondence: D. Agustina, c/o: Bagian Penyakit Mulut, Fakultas Kedokteran Gigi Universitas Gadjah Mada. Jln. Denta Sekip Utara Jogjakarta 55281, Indonesia.

\section{INTRODUCTION}

Oral cancer is a serious public health problem although the incidence of this disease is much lower in comparison with, other malignancies such as prostate, colon, breast and uteric cancers. Overall mortality rate of oral cancer remains high, at approximately $50 \%$, despite of modern medical services, which is probably due to the advanced stage of the disease at presentation. ${ }^{1}$ Around $86.8 \%$ of patients seeking medication usually have developed advanced condition or even metastatic. ${ }^{2}$ Those patients tend to have poor prognosis and low survival rate, resulting a short life expectancy. Conventional cancer treatment such as radiotherapy and chemotherapy often generate unfavorable effects to the patients, such as lowering the patient's immune system due to the destruction of normal cells. The extent of involved areas causing surgical treatment to create disfigurement and dysfunction of oral and facial tissues, which further leads to quality of life decrease in oral cancer patient. Based on these facts, currently more Indonesians return to the use of traditional herbal remedies as an empirical alternative therapy which is potential to cure cancers by loweing the side effects with a lower cost.
According to interview with local residents in Magelang, Jawa Tengah, Gynura procumbens (Lour) Merr has been long used to treat several cancers such as leukaemia, uteric and breast cancers. ${ }^{3}$ This plant is easily found in Indonesia and in various parts of South East Asia. Three fresh leaves are consumed daily for certain period of time, depending on the disease severity. Previous study reported that consumption of the ethanol extract of Gynura procumbens leaves might inhibit the occurrence of lung cancer up to $23 \%$ in newborn mice after being induced by benzopyrene on the first, eighth and fifteenth days. The extract dosage was equivalent to $100 \mathrm{mg}$ simplisia of Gynura procumbens leaves given twice weekly for 8 weeks. ${ }^{4}$ In vitro study also showed that the ethanol extract of Gynura procumbens leaves had a cytotoxic effect on myeloma cell culture with $\mathrm{LC}_{50}$ of $72 \mu \mathrm{g} / \mathrm{ml} .{ }^{5}$ Recent data demonstrated that the extract was also effective in inhibiting the pre-initiation and initiation phases of stomach carcinogenesis in Swiss mice after induction of benzopyrene, which is showed by, the percentage of animals bearing tumour and the number of tumour nodules. ${ }^{6}$ A Similar result also occurred which is in mammary carcinoma of Sprague Dawley rat induced by DMBA for 
10 times with a dosage of $20 \mathrm{mg} / \mathrm{kg}$ body weight during the initiation phase. The incidence of mammary carcinoma was reduced up to $40 \%$ until the end of the experiment. ${ }^{7}$ The most recent study showed an anti angiogenic effect of the ethanol extract of Gynura procumbens leaves on the chorioallantois membrane of chicken after bFGF induction. ${ }^{8}$

Those findings promote the anti carcinogenic potency of Gynura procumbens leaves for cancer therapy which should be elucidated in more detail. Current literatures, report no previous study or research on anti carcinogenic effect of the ethanol extract of Gynura procumbens leaves in oral carcinogenesis. In the light of different etiology that leads to different pathways in oral carcinogenesis, it is interesting to investigate the role of the ethanol extract of Gynura procumbens in inhibiting the oral carcinogenic process. The goal of the present study is to elucidate the inhibitory effect of the ethanol extract of Gynura procumbens leaves in oral carcinogenesis by comparing clinical and histopathological appearances in rat tongues between rats given 4 nitroquinoline 1-oxide (4NQO) and the extract with those given by $4 \mathrm{NQO}$ alone.

4 nitroquinoline 1 -oxide (4NQO) is a full carcinogenic agent. It can function either as an initiator or a promoter of cancer process. It can also be classified as an indirect carcinogen since it must be metabolically activated in vitro to produce "ultimate carcinogens", which are involved in the induction of tumours. ${ }^{9}$ Previous in vitro studies have been used 4NQO to induce malignancy in oral cavity, either by water drinking or direct application on oral mucosal tissue for a certain a period of time. ${ }^{10-14}$ Squamous cell carcinoma (SCC) produced by $4 \mathrm{NQO}$ behaved in a similar way to those of humans. ${ }^{11}$ According to Nauta et al. ${ }^{15}$ creating an oral carcinogenic model in rat by inducing $4 \mathrm{NQO}$ is appropriate to mimic a human oral carcinogenesis since they have similarities either in histopathologic or immunologic characteristics. The significance of this study may serve as scientific evidence for the industrial development of Gynura procumbens leaves as anti oral carcinogenic agent.

\section{MATERIALS AND METHODS}

Animals used in this study were 56 male Sprague Dawley rats $\left(\mathrm{F}_{54}\right)$, aged 4 weeks with average body weight of $63 \mathrm{~g}$ (PPOM, Food and Drug Research Center, Jakarta, Indonesia).

Carcinogen agent used was 4-nitroquinoline 1-oxide (4NQO) (Sigma Chemical Company, Australia), dissolved in propane-1,2-diol (PD) (Sigma Aldrich Chemic Gmbh, Germany) to a final concentration of $0.5 \%(\mathrm{~m} / \mathrm{v})$.

Ethanol extract of Gynura procumbens (Lour) Merr leaves was obtained by Soxhletation method, with $80 \%$ ethanol and suspended in $0.5 \mathrm{ml}$ aquadest.

4 nitroquinoline 1-oxide (4NQO) solution was applied using a no. 2 artists' brush which delivered a relatively constant volume $(0.15 \mathrm{mg})$. A single brush stroke was applied from posterior to anterior of the dorsal surface of rat tongue three times weekly. The extract was given through oral intubation twice weekly with a dosage per administration equivalent to $3.5 \mathrm{~g}$ dry leaves (simplisia)/kg body weight.

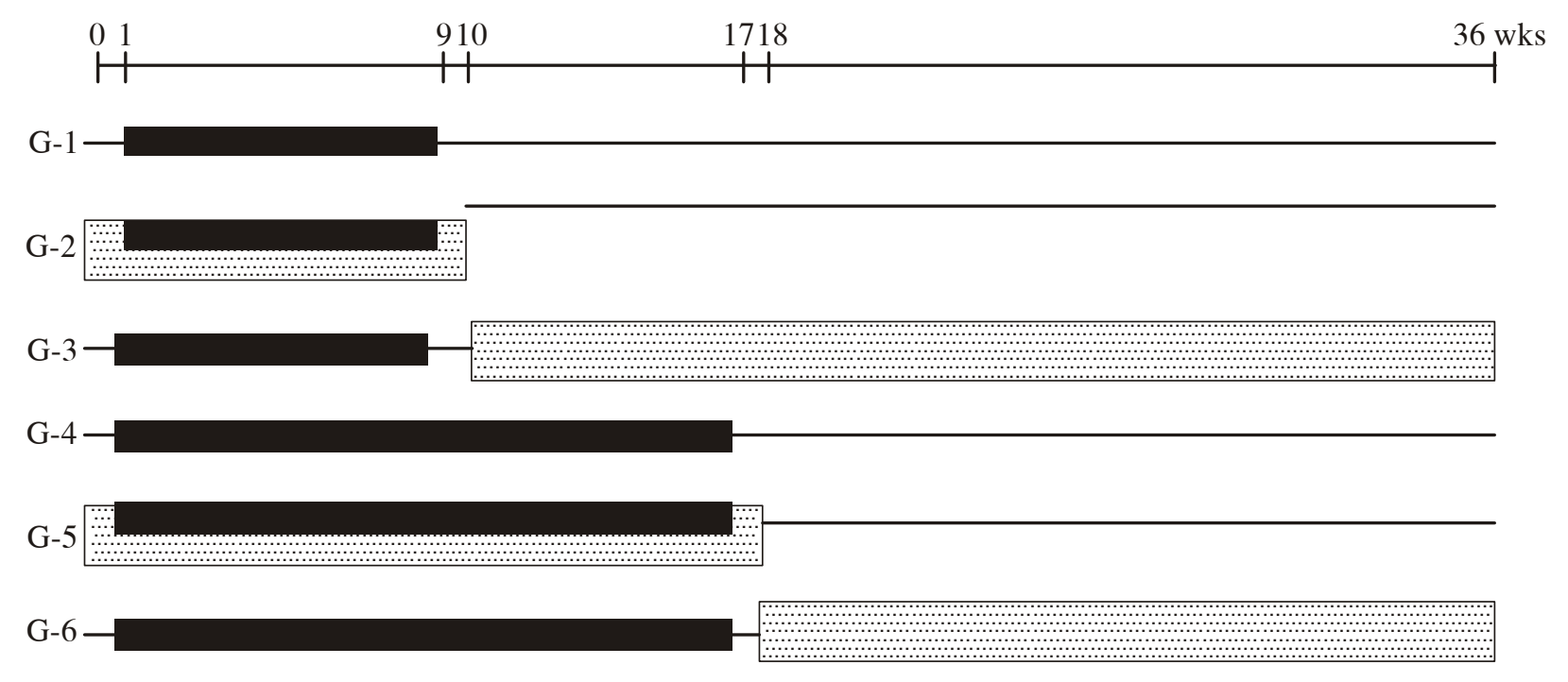

G-7

: 4NQO application
administration
$:$ diet and tap water ad libitum
: ethanol extract of Gynura procumbens leaves

Figure 1. Design of the study. 
Design of the study (Figure 1): Group $1(n=6)$ consisted of rats given 4NQO alone for 8 weeks (4NQO-8 wk); Group $2(n=9)$ consisted of rats given 4NQO for 8 weeks and the extract simultaneously. The ethanol extract of Gynura procumbens was administered for 10 weeks commencing one week before the 4NQO exposure and terminated one week after 4NQO induction finished (4NQO-8 wk + extract); Group $3(n=11)$ consisted of rats given 4NQO for 8 weeks and the extract afterwards. The extract was administered for 26 weeks, starting 1 week after the cessation of 4NQO treatment until the end of the experiment (4NQO-8 wk $\rightarrow$ extract); Group $4(n=9)$ consisted of rats given 4NQO alone for 16 weeks (4NQO-16 wk); Group 5 $(n=9)$ consisted of rats given 4NQO for 16 weeks and the extract simultaneously. The ethanol extract of Gynura procumbens was administered for 18 weeks commencing one week before the 4NQO exposure and terminated one week after 4NQO induction finished (4NQO-16 wk + extract); Group $6(n=6)$ : rats were given 4 NQO for 16 weeks and the extract afterwards. The extract was administered for 18 weeks, starting 1 week after the cessation of 4NQO treatment until the end of the experiment (4NQO-16 wk $\rightarrow$ extract); Group $7(n=6)$ served as an untreated control group.

Animal experimentation: Every 2-4 rats were housed in stainless steel and plastic cages at constant humidity $(50-55 \%)$ and temperature $\left( \pm 25^{\circ} \mathrm{C}\right)$ with 12 hours light in the Animal House of Pharmacology and Toxicology Department, Faculty of Pharmacy, Gadjah Mada University, Jogjakarta, Indonesia. They were fed AD-II pellets (PT Japfa, Sidoarjo, Indonesia) and had tap water available ad libitum.

During the course of study, the animals were weighed biweekly and general inspection of the general health was carried out daily to record any macroscopic changes. Should the general condition deteriorate significantly, the rat was terminated by overdosed ether. To observe the progression of tongue carcinogenesis, three rats from groups 1, 2, 3, 4, 5 , and 7 were terminated in the middle of the experiment period (the 19th week) to allow histological examination. At the end of the $36^{\text {th }}$ week, all animals were terminated and all tongues and other organs of rats detected with pathological lesions were removed. For histological examination, tissues and gross lesions were fixed in $10 \%$ buffered formalin, embedded in paraffin blocks and stained with hematoxylin-eosin (H-E). Tongue lesions were diagnosed according to the criteria of WHO: "Histological Typing of Cancer and Precancer of the Oral Mucosa".16

\section{RESULTS}

At the beginning of the experiment, both the experimental and control groups appeared to be in good health assessed by subjective assessment of their physical mobility and fur luster. There was no significant difference of the body weight among the groups of the experiment at the end of the study. In general, the health of the experimental rats throughout the experimental period appeared poorer than that of the untreated rats.

Three rats from groups 1, 2, 3, 4, 5, and 7 (total: 18 rats) were terminated in the middle of the experiment for observation of carcinogenesis progression. Histological assessment to those tongues demonstrated no dysplastic changes occurred in groups 1 (4NQO-8 wk), 2 (4NQO-8 $\mathrm{wk}+$ extract) and 3 (4NQO-8 wk $\rightarrow$ extract). However, each one of three rats from groups 4 (4NQO-16 wk) and 5 (4NQO-16 wk + extract) had tongue SCC. The tongue of three rats from group 7 (untreated control) remained normal.

Nineteen $(50 \%)$ rats survived until the end of the experiment (the $36^{\text {th }}$ week), however the other nineteen (50\%) had to be necropsied before the end of the experiment. Three of group 2, five of group 3, two of group 4 , five of group 5 and four of group 6 failed to survive until the $36^{\text {th }}$ week. Possible causes of deaths were the presence of tongue SCC (10 of 19 rats, 53\%) and systemic problems (9 of 19 rats, $47 \%$ ) such as chronic respiratory disease (CRD), splenomegaly and liver infection of Taenia crassicollis. Those systemic problems were also noted in the survivors (17 of 19 rats, 89\%). Determination of systemic problems presence was based on histopathological

Table 1. Histopathological examination of 38 rats's tongues from rats necropsied either before or at the end of the experiment

\begin{tabular}{ccccccccccr}
\hline & \multicolumn{10}{c}{ Histopathological Examination } \\
\hline Group & No. of rats & $\mathrm{N}$ & $\mathrm{H}$ & MiD & MoD & SeD & CIS & MieSCC & WellSCC & SCC Incidence (\%) \\
\hline 1 & 3 & 0 & 0 & 0 & 0 & 0 & 0 & 1 & 2 & 100 \\
2 & 6 & 0 & 3 & 1 & 0 & 0 & 0 & 0 & 2 & 33.3 \\
3 & 8 & 0 & 3 & 1 & 1 & 1 & 0 & 0 & 2 & 25 \\
4 & 6 & 0 & 0 & 0 & 1 & 0 & 0 & 1 & 5 & 100 \\
5 & 6 & 0 & 0 & 0 & 0 & 0 & 1 & 0 & 5 & 83.3 \\
6 & 6 & 0 & 0 & 0 & 1 & 0 & 0 & 0 & 0 & 0 \\
7 & 3 & 3 & 0 & 0 & 0 & 0 & 0 & 0 & 0 & 0 \\
\hline
\end{tabular}

Group 1: 4NQO-8 wk; Group 2: 4NQO-8 wk + extract; Group 3: 4NQO-8 wk $\rightarrow$ extract; Group 4: 4NQO-16 wk; Group 5: 4NQO-16 wk + extract; Group 6: 4NQO-16 wk $\rightarrow$ extract; Group 7: untreated control; N: Normal; H: Hyperplasia; MiD: Mild Dysplasia; MoD: Moderate Dysplasia; SeD: Severe Dysplasia; CIS: Carcinoma in situ; MicSCC: Micro-invasive Squamous Cell Carcinoma; WellSCC: Well Differentiated Squamous Cell Carcinoma; For SCC Incidence, CIS, MicSCC and WellSCC were categorized as SCC. 
Table 2. Percentage according to histopathological diagnosis in groups of study

\begin{tabular}{lrrrrrrr}
\hline \multicolumn{8}{c}{ Group of Study } \\
\hline \multicolumn{1}{c}{ Diagnosis } & \multicolumn{1}{c}{2} & \multicolumn{1}{c}{3} & \multicolumn{1}{c}{4} & \multicolumn{1}{c}{5} & \multicolumn{1}{c}{6} & \multicolumn{1}{c}{7} \\
\hline Normal & 0 & 0 & 0 & 0 & 0 & 0 & 100 \\
Hyperplasia & 0 & 50 & 37.5 & 0 & 0 & 0 & 0 \\
Dysplasia & 0 & 16.7 & 37.5 & 0 & 0 & 16.7 & 0 \\
SCC & 100 & 33.3 & 25 & 100 & 100 & 83.3 & 0 \\
\hline
\end{tabular}

SCC: Squamous cell carcinoma

examination with HE staining.

Macroscopical or clinical appearances of 38 rat tongues showed hyperkeratosis, white, granular/nodular, thickening (Figure 3), ulcerative (Figure 4) lesions or the presence of tumor mass (Figure 5) on the posterior dorsal surface of the tongue, which could be clearly differentiated from the normal condition (Figure 2). Lesion diagnosed as well differentiated SCC might have macroscopical appearance as hyperkeratosis, granular/nodular, thickening, ulcerative lesions or tumor mass.

Results histopathological examination of HE sections on 38 rats' tongues from rats necropsied either before or

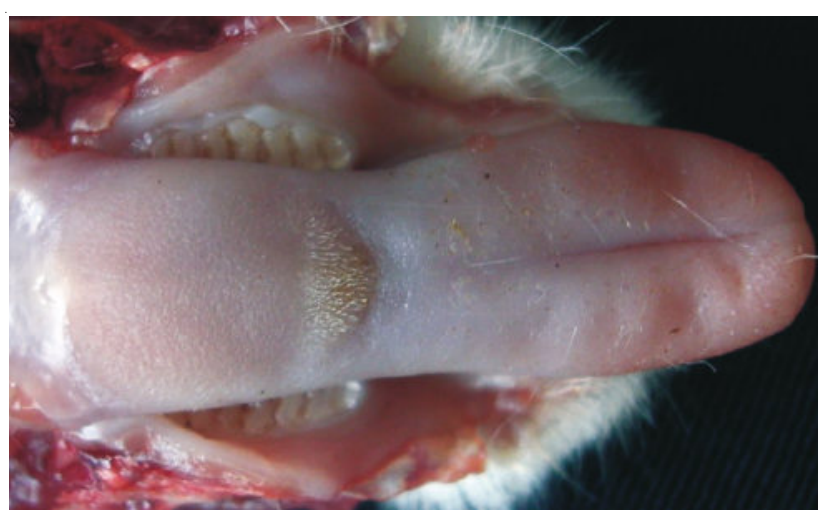

Figure 2. Macroscopical appearances of dorsal surface of rat tongue indicated as normal appearance from untreated control group.

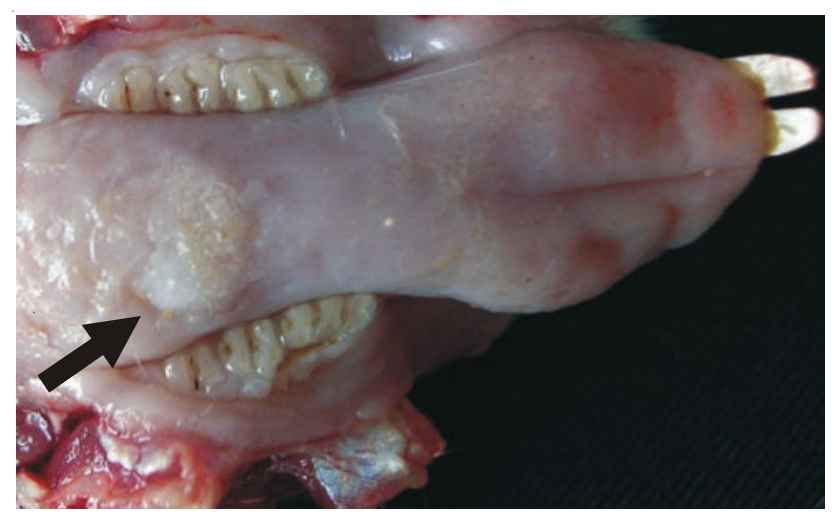

Figure 3. A white thickening lesion (an arrow) taken from a rat from group 2 (4NQO-8 wk + extract) that has been histologically diagnosed as hyperplasia. after the experiment are shown in Table 1 (note: 18 rats necropsied in the middle of the experiment were not included). Percentage according to histopathological diagnosis in groups of study is demonstrated in Table 2 and on Figure 6 in which mild, moderate and severe dysplasia were categorized as dysplasia and carcinoma in situ (CIS), micro-invasive SCC and well differentiated SCC were grouped together in SCC.

Normal histological appearance of the dorsal surface of the rat tongue is characterized by regular epithelial stratification. There is no epithelial down growth and polarity of the basal cells is significantly present (Figure 7). Moderate hyperplasia was especially demonstrated by epithelial down growth and basal and spinous cells proliferation. On the other hand, bulbous rete ridges was relatively prominent as well (Figure 8). Severe dysplasia showed that more severe atypic cells involving the whole thickness of epithelial layer, irregular epithelial stratification and loss of intercellular adherence (Figure 9). Well differentiated SCC was characterized by the prominent appearance of keratinization on tumor cells more than $75 \%$ and many tumor nests infiltrated into lamina propria even deeper to musculatory area (Figure 10).

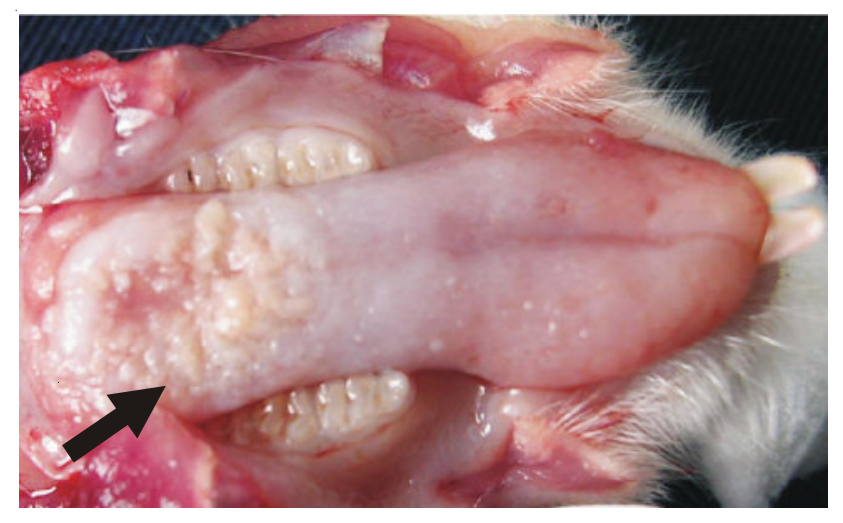

Figure 4. An ulcerative lesion (an arrow) taken from a rat from group 3 (4NQO-8 wk $\rightarrow$ extract) that has been histologically diagnosed as well differentiated SCC.

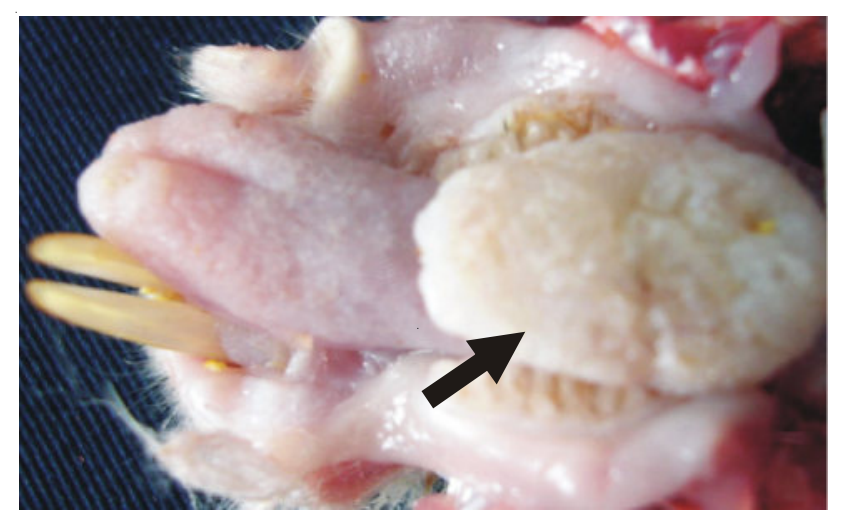

Figure 5. A tumor mass (an arrow), a pedunculated lesion taken from a rat from group 4 (4NQO-16 wk) that has been histologically diagnosed as well differentiated SCC. 


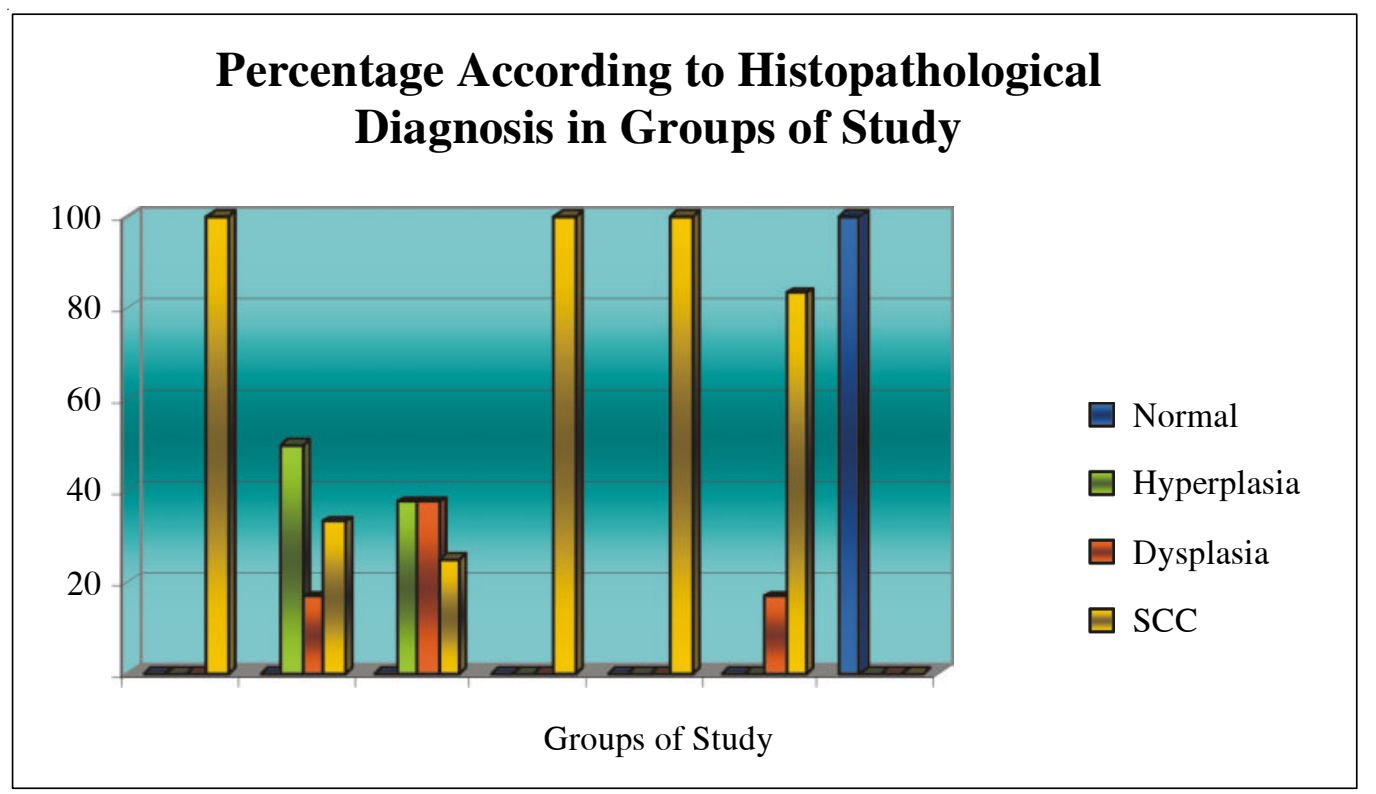

Figure 6. Percentage based on the histopathological assessment of lingual mucosa of 7 groups of rats used in this study.

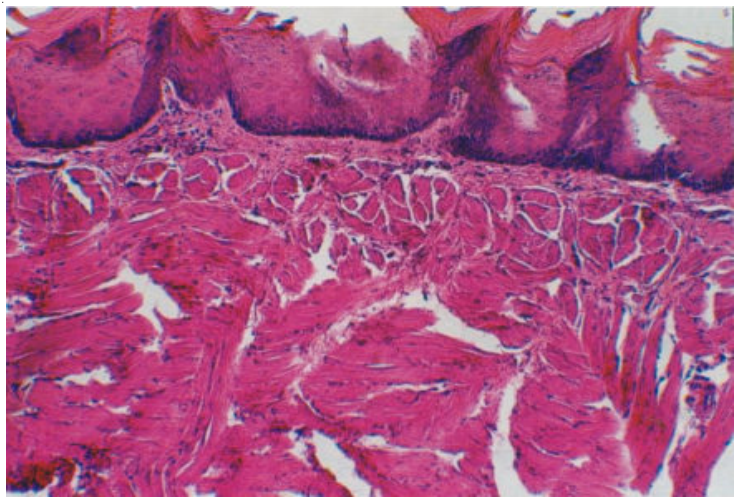

Figure 7. Microscopical appearances of dorsal surface of rat tongue indicated as normal appearance from untreated control group, H\&E, 100X.

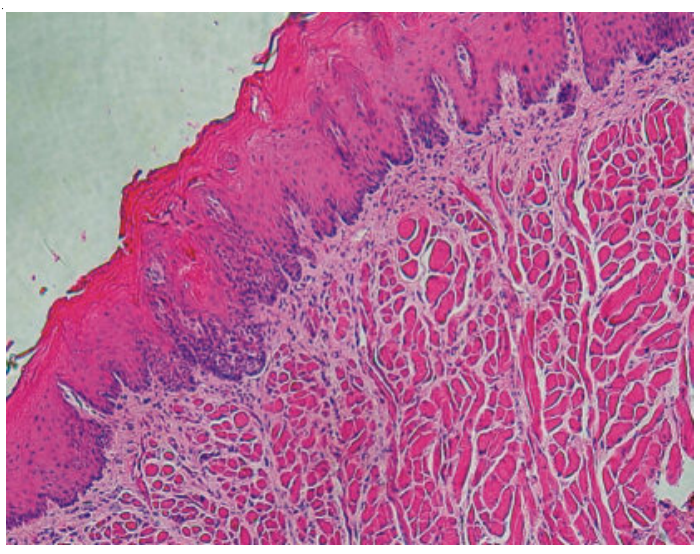

Figure 8. Moderate hyperplasia, H\&E, 100X taken from a rat from group 3 (4NQO-8 wk $\rightarrow$ extract).

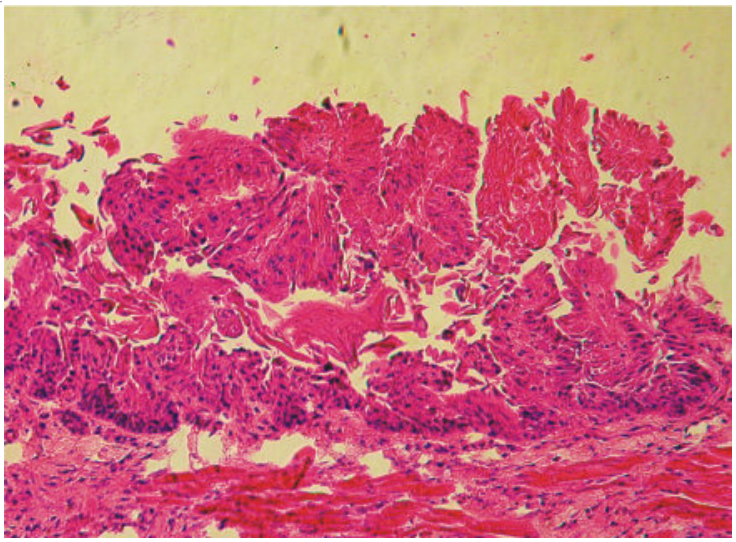

Figure 9. Severe dysplasia, H\&E, 200X taken from a rat from group 3 (4NQO-8 wk $\rightarrow$ extract).

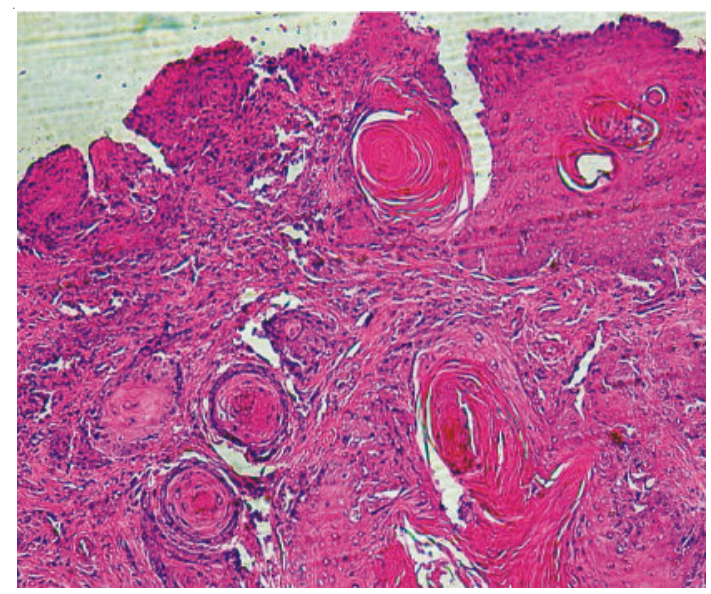

Figure 10. Well differentiated SCC, H\&E, 100X taken from a rat from group 1 (4NQO-8 wk). 


\section{DISCUSSION}

Decreased general health in treated rats was especially the result of the $4 \mathrm{NQO}$ treatment. $4 \mathrm{NQO}$ treatment led to the presence of a big tumor mass on the dorsal surface of the tongue caused rats to have difficulties in eating, causing limitation of food consumption. On the other hand, the long duration of the experiment caused rats more susceptible to many infection from their environment. This assumption was based on the finding that almost $50 \%$ of unsurviving rats and $89 \%$ of surviving rats had CRD, splenomegaly or liver infection of worm cyst such as Taenia crassicollis. This incidence suggests that the longer the experimental duration the more susceptible the animals are to infectious agents. The severity of infection was indicated by the number of animals suffering splenomegalies. Other factors that contribute to CRD and liver infection by Taenia crassicollis were sanitation, maintenance and humidity of the bedding. In this study, replacement of the cage, drinking bottle and bedding were carried out once a week. Infection might be prevented by more frequent sanitation maintenance. ${ }^{17}$

Histopathological examination on rat tongue in the middle of the experiment (the $19^{\text {th }}$ week) to observe the progression of tongue carcinogenesis indicated that the longer the 4NQO induction the earlier tongue SCC will develop. This statement is supported by the finding that no SCC developed until the $19^{\text {th }}$ week in rats given 4 NQO for 8 weeks. However, two out of 6 rats developed tongue SCC by the $19^{\text {th }}$ week in groups induced by 4 NQO for 16 weeks. This means that longer 4NQO induction might cause more genetical changes, leading to a faster progression of the carcinogenic process.

According to Tanaka et al., ${ }^{18}$ the initiation phase in 4NQO-induced tongue carcinogenesis in rat was achieved by 4 NQO induction for $\leq 10$ weeks. The data on the incidence of tongue neoplasms among the groups 1,2 and 3 (Table 1) indicated that administration of ethanol extract of Gynura procumbens leaves on the initiation phase (8 wk $4 \mathrm{NQO}$ induction) could suppress the progression of tongue carcinogenesis in the models used. However, the inhibition was more effective if the extract was given in a longer period than $4 \mathrm{NQO}$ induction after the animals have been initiated as conducted in group 3 in which the reduction of tongue SCC incidence was up to $75 \%$. If the administration of the extract was calculated, rats in group 2 were only given the extract for 10 weeks, but rats in group 3 were given the extract for 26 weeks. It suggests that the longer the administration of the extract against the induction of carcinogen, the more the suppression on oral carcinogenesis leading to a lower incidence of tongue SCC. The above assumption was proven by the results of groups 4, 5 and 6 were compared. It was clear that in the groups 5 and 6 , the duration of $4 \mathrm{NQO}$ induction compared to that of the extract administration was not so different (the 4NQO: $16 \mathrm{wk}$, the extract: $18 \mathrm{wk}$ ), so the inhibition of tongue carcinogenesis could not be achieved. Apparently, more frequency of extract administration was needed to be able to inhibit the progression of tongue carcinogenesis.

Our study suggests that Gynura procumbens leaves are possible new dietary preventive agents against tongue carcinogenesis. Anticarcinogenic component contained in the leaves is especially flavonoids. Flavonoids are found include in polyphenolic compounds that might be able to dysregulate cancer development. These include antioxidant activities, ${ }^{19}$ the scavenging effect on activated carcinogens and mutagens, ${ }^{20,21}$ the action on proteins that control cell cycle progression, ${ }^{22}$ and altered gene expression. ${ }^{23}$ The core structure of the flavonoids, 2-phenyl-4H-1-benzopyran-4one (flavone) affects proliferation, differentiation, and apoptosis in human colon carcinoma cell line. Even its apoptotic inducer is stronger than clinically established anti tumour agent, camptothecin. ${ }^{24}$ The results of the study corroborated the results of the previous investigations that administration of ethanol extract of Gynura procumbens leaves could block the pre-initiation and initiation phases of stomach carcinogenesis in Swiss mice induced with benzopyrene ${ }^{6}$ and that of mammary carcinoma in Sprague Dawley rat induced by $\mathrm{DMBA}^{7}$ and the extract could reduce the occurrence of lung tumor up to $23 \%$ in new born mice after being of after induction with benzopyrene. ${ }^{4}$

In conclusion, the results of our study demonstrate the inhibitory effect of ethanol extract of Gynura procumbens (Lour) Merr leaves in the initiation phase of 4NQO-induced tongue carcinogenesis in rats especially viewed from clinical and histopathological aspects. Further experiments to elucidate the inhibitory mechanism of Gynura procumbens leaves in molecular level is strongly recommended for the development of chemopreventive agent of Gynura procumbens in oral carcinogenesis.

\section{ACKNOWLEDGEMENTS}

This study was a part of AD's Ph.D. research partially supported by BPPS Funding of the Indonesian Government, Hibah Bersaing XII Project of the Indonesian Government (2004), Human Resources Development of Gadjah Mada University and by Research Institution of Gadjah Mada University (DIPA).

\section{REFERENCES}

1. Walker DM, Boey G, McDonald LA. The pathology of oral cancer. Pathology 2003; 35(5): 376-83.

2. Sajid M. Frequency of the oral cancer at the Dental Clinic of the Dr. Sardjito Hospital during 3 years. Scientific Abstracts-Free Paper Session on First International Congress on Oral Cancer and Jaw tumours, Singapore, 1987.

3. Sudarto B. Daya antibakteri minyak atsiri daun dewa (Gynura procumbens (Lour) Merr. Laporan Penelitian. 1,3. Jogjakarta: Fakultas Farmasi UGM; 1991. h. 3.

4. Sugiyanto, Sudarto B, Meiyanto E. Efek penghambatan karsinogenisitas benzo(a)piren oleh preparat tradisional tanaman Gynura sp. dan identifikasi awal senyawa yang berkhasiat. Laporan Penelitian P4M DitJen DikTi. Jogjakarta: Fakultas Farmasi UGM; 1993. h. 29-51. 
5. Arianti S. Aktivitas biologis ekstrak etanol daun Gynura procumbens (Lour) Merr terhadap sel vero dan sel mieloma. Skripsi. Jogjakarta: Fakultas Farmasi UGM; 1998. h. 26-46.

6. Ulfa EM. Pengaruh pemberian ekstrak etanol daun Gynura procumbens (Lour) Merr pada pre-inisiasi sampai fase inisiasi pertumbuhan tumor lambung mencit karena Benzo(a)piren. Skripsi. Jogjakarta: Fakultas Farmasi UGM; 2000. h. 39-57.

7. Susilowati S. Efek kemopreventif ekstrak etanolik daun Gynura procumbens (Lour) Merr terhadap kanker payudara tikus yang diinduksi 7,12-Dimetil benz(a) antrasen (DMBA). Tesis. Jogjakarta: Pascasarjana UGM; 2004. h. 44-70.

8. Jenie RI, Meiyanto E, Murwanti R. Efek antiangiogenik ekstrak etanolik daun Sambung Nyawa (Gynura procumbens (Lour) Merr) pada membran korio alantois (CAM) embrio ayam. Majalah Farmasi Indonesia 2006; 17(1):50-5.

9. Miller EC. Some current perspectives on chemical carcinogenesis in humans and experimental animals: presidential address. Cancer Res 1978; 38:1479-96.

10. Wallenius K, Lekholm U. Oral cancer in rat induced by the watersoluble carcinogen 4-nitroquinoline N-oxide. Odont Revy 1973; 24:39-48.

11. Steidler NE, Reade PC. Experimental induction of oral squamous cell carcinomas in mice with 4-nitroquinoline 1-oxide. J Oral Surg 1984; 57:524-31.

12. Steidler NE, Rich AM, Reade PC. Experimental induction of preneoplastic and neoplastic changes in the lingual mucosa of rats. J Biol Buccale 1985; 13:339-46.

13. Ohne M, Satoh T, Yamada S, Takai H. Experimental tongue carcinoma of rats induced by oral administration of 4-nitroquinoline 1-oxide (4NQO) in drinking water. Oral Surg Oral Med Oral Pathol 1985; 59:600-7.
14. Prime SS, Malamos D, Rosser T, Scully C. Oral epithelial atypia and acantholytic dyskeratosis in rats painted with 4-nitroquinoline N-oxide. J Oral Pathol 1986; 15:280-83.

15. Nauta JM, Roodenburg JLN, Nikkels PGJ, Witjes MJH, Vermey A. Comparison of epithelial dysplasia: the 4NQO rat palate model and human oral mucosa. Int J Oral Maxillofac Surg 1995; 24:53-58.

16. Pindborg JJ, Reichart PA, CJ Smith CJ, van der Waal I. World Health Organization International Histological Classification of Tumours: Histological Typing of Cancer and Precancer of the Oral Mucosa. $2^{\text {nd }}$ ed. Berlin: Springer; 1997. p. 11-13, 24-26, 28, 44-46, 68-69, 81.

17. Smith JB, Mangkoewidjoyo. Pemeliharaan, pembiakan dan penggunaan hewan percobaan di daerah tropis. $1^{\text {st }}$ ed. Jakarta: UI Press; 1988. p. 49-54.

18. Tanaka T, Kohno H, Sakata K, Yamada Y, Hirose Y, Sugie S, Mori H. Modifying effects of dietary capsaicin and rotenone on 4-nitroquinoline 1-oxide-induced rat tongue carcinogenesis. Carcinogenesis 2002; 23(8):1361-67.

19. Duthie SJ, Dobson VL. Dietary flavonoids protect human colonocyte DNA from oxidative attack in vitro. Eur J Nutr 1999; 38:28-34.

20. Williamson G, Faulkner K, Plumb GW. Glucosinolates and phenolics as antioxidants from plant foods. Eur J Cancer Prev 1998; 7:17-21.

21. Calomme M, Pieters L, Vlietinck A, Vanden Berghe D. Inhibition of bacterial mutagenesis by citrus flavonoids. Planta Med 1996; 62:222-6.

22. Plaumann B, Fritsche M, Rimpler H, Brandner G, Hess RD. Flavonoids activate wild-type p53. Oncogene 1996; 13:1605-14.

23. Gerritsen ME. Flavonoids: inhibitors of cytokine induced gene expression. Adv Exp Med Biol 1998; 439:183-90.

24. Wenzel U, Kuntz S, Brendel MD, Daniel H. Dietary flavone is a potent apoptosis inducer in human colon carcinoma cells. Cancer Res 2000; 60:3823-31. 